\title{
TINJAUAN HISTOLOGIK TULANG RAWAN
}

\author{
Sonny J. R. Kalangi \\ Bagian Anatomi-Histologi Fakultas Kedokteran Universitas Sam Ratulangi Manado \\ Email: sonnykalangi@yahoo.com
}

\begin{abstract}
Cartilage belongs to the suppportive tissue which is relatively dense. In an adult, this tissue is only found in two areas: extraskeletal cartilage and joints. During chondrogenesis in an embryo, messenchymal cells round up, retract their extensions, multiply rapidly, and form cellular condensation, cartilage formation area. The development of this ares occurs in two mechanisms: interstitial growth and apppositional growth. Injured cartilage will be repaired by the perichondrium. Its cells tend to fill spaces or deffects meanwhile chondrogenic cells of the perichondrium will undergone proliferation and differentiation to become chondroblast which produces new matrix.
\end{abstract}

Keywords: cartilage, types of cartilage

\begin{abstract}
Abstrak: Tulang rawan merupakan jaringan ikat penahan berat yang relatif padat, tetapi tidak sekuat tulang. Dalam kehidupan pasca lahir, jaringan ini hanya ditemukan pada dua jenis tempat sesudah tidak tumbuh lagi, yaitu pada sejumlah bangunan tulang rawan ekstra-skeletal yang terdapat dalam tubuh dan pada persendian. Pada tempat pembentukan tulang rawan embrio, sel-sel mesenkim menyusutkan cabang-cabangnya dan mengumpul dalam agregasi padat yang dikenal sebagai pusat kondrifikasi. Pertumbuhan dalam perluasan pusat kondrifikasi terjadi melalui dua mekanisme berbeda, yaitu: pertumbuhan interstitial dan pertumbuhan aposisional. Cedera tulang rawan akibat trauma akan diperbaiki oleh perikondrium. Sel-sel perikondrium cenderung untuk mengisi kekosongan atau defek, sedangkan sel-sel kondrogenik dalam perikondrium akan berproliferasi dan berdiferensiasi menjadi kondroblas yang menghasilkan matriks baru.
\end{abstract}

Kata kunci: kartilago, jenis kartilago

Tulang rawan (L. cartilago, tulang muda) merupakan jaringan ikat penahan-berat yang relatif padat, tetapi tidak sekuat tulang. Dalam kehidupan pasca lahir sesudah tidak tumbuh lagi, jaringan ini hanya ditemukan pada dua jenis tempat.

Tempat pertama, sejumlah bangunan tulang rawan ekstra-skeletal terdapat dalam tubuh. Sebagai contoh ialah cincin-cincin tulang rawan berbentuk tapal kuda pada dinding trakea. Peranan cincin ini ialah mencegah dinding trakea, yang sebenarnya hanya terdiri atas jaringan ikat biasa, agar tidak kolaps saat udara dihirup memasuki paru. Bangunan tulang rawan berbentuk tidak beraturan juga terdapat pada dinding jalan napas yang lebih kecil yang menunju paru. Juga terdapat lempeng-lempeng tulang rawan pada laring, hidung, dan dinding bagian medial tuba auditori (yang menghubungkan telinga tengah dengan nasofaring dan memungkinkan terjadinya keseimbangan tekanan udara antara kedua rongga itu). Tulang rawan juga terdapat pada tulang iga (yang menghubungkan ujung anterior iga dengan sternum), berupa bagian yang menghubungkan iga-iga dengan sternum yang kuat namun cukup fleksibel sehingga memungkinkan kerangka iga meluas pada gerakan respirasi. 
Tempat kedua tertinggalnya tulang rawan seumur hidup ialah pada persendian. Pada sendi yang bergerak bebas, ujungujung tulang dibalut tulang rawan. Dalam hal ini tulang rawan itu disebut tulang rawan sendi, dan unsur interselnya (yang dikenal sebagai matriks) membentuk permukaan pelincir yang licin pada ujung sendi tulang. Tulang rawan juga terdapat pada beberapa sendi yang tidak dapat bergerak bebas.

Umumnya tulang rawan yang terbentuk semasa kehidupan pra-lahir hanya bersifat sementara karena akan diganti dengan tulang, namun pembentukannya merupakan tahapan menentukan dalam perkembangan tulang panjang. Lagi pula sejumlah tulang rawan demikian yang menetap sampai penumbuhan pasca lahir telah berakhir, merupakan alat penumbuh memanjang tulang.

Tulang rawan biasa disebut sebagai tulang rawan hialin (Yun. hyalos) karena matriksnya tampak putih kebiruan mirip mutiara dan agak tembus cahaya dalam keadaan segar. Namun pada beberapa tempat terdapat tulang rawan elastis karena juga mengandung serat-serat elastin, dan pada tempat lain lagi mengandung banyak kolagen sehingga pantas disebut sebagai fibrokartilago.

\section{PERTUMBUHAN TULANG RAWAN}

Pada tempat pembentukan tulang rawan dalam embrio, sel-sel mesenkim menyusutkan cabang-cabangnya dan mengumpul dalam agregasi padat yang dikenal sebagai pusat kondrifikasi. Selselnya sangat berdekatan dan batas-batasnya tidak jelas. Dengan memperbesar dan berkembangnya sel prekursor ini, mereka mensekresikan ke sekitarnya matriks amorf metakromatik. Kolagen disekresikan bersamaan, namun serabut yang dibentuk tertutup oleh matriks hialin yang membuat kolagen terpendam. Dengan bertambahnya jumlah materi interstisial ini, maka selselnya terisolasi dalam kompartemen masing-masing atau lakuna dan berangsur memperoleh ciri sitologik kondrosit dewasa.
Dalam perluasan pusat kondrifikasi, pertumbuhan terjadi melalui dua mekanisme berbeda, yaitu: pertumbuhan interstitial dan pertumbuhan aposisional.

\section{Pertumbuhan interstisial}

Satu hal yang perlu ditetapkan di sini, yang akan bermanfaat saat membicarakan perkembangan tulang panjang serta pertumbuhannya ialah bahwa salah satu cara pertumbuhan tulang rawan ialah melalui pertumbuhan interstisial. Dengan kata lain, walaupun kondrosit muda telah terbenam di dalam matriks tulang rawan, sel tersebut tetap dapat membelah, kemudian masingmasing sel anak menghasilkan matriks yang mengakibatkan matriks tulang rawan secara keseluruhannya mengembang dari dalam.

Di bagian dalam tulang rawan yang berkembang, sel-selnya untuk waktu tertentu, masih dapat membelah. Setelah telofase, sekresi matriksnya membentuk sekat yang makin tebal di antara sel-sel anak sehingga mereka menempati lakuna terpisah. Sel-sel ini, pada gilirannya, kemudian membelah, menghasilkan kelompok empat kondrosit dalam lakuna bersebelahan. Pengembangan tulang rawan melalui pembentukan sel-sel dan matriks baru dari dalam disebut pertumbuhan interstisial dan menerangkan terdapatnya pasangan dan kelompok empat atau lebih lakuna dalam tulang rawan dewasa. Setiap kelompok dikatakan isogen karena merupakan turunan dari satu kondrosit yang mengalami beberapa kali pembelahan sebelum berhenti. Matriks tepat mengelilingi setiap kelompok sel isogen terpulas lebih gelap. Halo lebih basofilik ini disebut sebagai matriks teritorial dan daerah kurang basofilik lain diantara kelompok-kelompok sel disebut matriks interteritorium.

Pada tulang rawan epifisis tulang panjang yang tumbuh, pertumbuhan interstisial tetap ada dan pembelahan sel dalam orientasi tetap ada dan pembelahan sel dalam orientasi tetap menghasilkan lakuna tersusun dalam kolom memanjang 
paralel terhadap sumbu panjang tulang. Sel-sel pada ujung metafisis kolom ini berdegenerasi dan lakunanya dimasuki tulang yang makin maju.

\section{Pertumbuhan aposisional}

Cara lain pertumbuhan tulang rawan ialah dengan meletakkan lebih banyak matriks pada permukaannya. Mekanisme pertumbuhan ini disebut sebagai pertumbuhan aposisional. Mekanisme pertumbuhan ini bergantung pada pembentukan kondroblas penghasil matriks baru pada permukaan tulang rawan.

Mesenkim yang mengelilingi tulang rawan memadat membentuk perikondrium. Sel-sel pada aspek dalamnya, disebut sebagai lapis kondrogeniknya, berproliferasi, berkembang menjadi kondrosit, dan menghasilkan matriks di sekitarnya, sehingga terkurung di dalam tulang rawan. Penambahan sel dan matriks baru pada permukaan ini disebut pertumbuhan aposisional, kesanggupan perikondrium membentuk tulang rawan berlanjut sampai ke pasca-lahir dan membantu pertumbuhan diameter model tulang rawan dari tulang panjang.

\section{Kondrosit}

Sel-sel ini terdapat tepat di bawah perikondrium dan di bawah permukaan bebas tulang rawan sendi, lakunanya lonjong dengan sumbu panjangnya paralel terhadap permukaan, sedangkan di bagian tulang rawan lebih dalam, mereka berbentuk setengah bulatan atau bersiku. Pada tulang rawan hidup, mereka menyesuaikan diri dengan bentuk lakunanya, namun pada sediaan histologik mereka sering berbentuk stelata akibat pengerutan dan retraksi permukaannya dari dinding lakuna. Inilah artifak pembuatan sediaan yang kurang nampak pada sediaan untuk mikroskop elektron, namun di sini pun mutu pengawetannya kurang ideal. Sitoplasma biasanya kurang padat dan kadang-kadang mengandung tetes lipid dan glikogen dalam jumlah bervariasi. Kompleks Golgi jukstanukleus bervakuol dan sisterna dari retikulum endoplasma sering mengembang. Mitokondrianya mungkin berubah bentuk dan memiliki matriks berdensitas rendah. Jelas bahwa struktur ultra kondrosit kurang terawetkan dengan metode rutin pembuatan sediaan daripada jenis sel lain. Meskipun begitu, mikrograf elektron jaringan yang dibuat dengan beku tekanan-tinggi dan substitusibeku diikuti pemendaman suhu rendah, lebih representatif tentang keadaannya in vivo. Terdapat sedikit vakuol sitoplasma, matriks mitokondria padat, dan hanya sedikit atau tidak ada sama sekali pelebaran sisterna dari Golgi atau dari retikulum endoplasma.

Bila kondrosit aktif membuat komponen matriks, sitoplasmanya akan lebih basofilik, dan pada mikrograf elektron, kompleks Golgi mencolok dan retikulum endoplasma lebih luas.

\section{MATRIKS TULANG RAWAN}

Matriks tulang rawan pada dasarnya merupakan gel amorf berpegas dengan susunan makromolekul khusus. Gel ini terutama terdiri atas proteoglikan, selain sedikit protein dan glikoprotein. Di dalam gel tersebar serat kolagen halus yang dibentuk oleh kolagen tipe II. Serat kolagen halus ini cukup kuat untuk dilihat dengan MC karena hanya berdiameter $10 \mathrm{~nm}$ sampai $100 \mathrm{~nm}$. Perkiraan kandungan kolagen minimal dan maksimal pada matriks tulang rawan ialah $40 \%$ dan $70 \%$ berat keringnya, namun masih ada variasi sumbunya. Lebih kurang setengah dari matriks organik terdapat berupa gel yang terutama terdiri atas proteoglikan tulang rawan yang hidrofilik kental.

Seperti halnya kolagen tipe II, proteoglikan tulang rawan dihasilkan setempat oleh kondrosit. Ciri tambahan yang khas untuk matriks tulang rawan ialah terdapatnya penimbunan proteoglikan supramolekular; kandungan proteoglikan merupakan dasar molekular daya pegasnya yang luar biasa.

Kebanyakan proteoglikan tulang rawan terdapat berupa agregrat proteoglikan. 
Sampai lebih kurang 100 molekul proteoglikan, masing-masing konfigurasi sesuai dengan gambaran proteoglikan heparan sulfat, mungkin tersusun berderet sepanjang molekul asam hialuronat. Agregat proteoglikan yang dihasilkan menyerupai botol bersikat dengan sejumlah bulu yang sesuai. Namun setiap bulu akan memiliki konfigurasi mirip lipan karena memiliki rantai glikosaminoglikans yang menjulur ke lateral.

Sumbu panjang botol sikat dalam analog ini ialah molekul linear asam hialuronat terentang. Setiap molekul proteoglikan yang terjulur ke samping berupa sikat terdiri atas (1) molekul protein pusat aksial panjang dengan (2) sejumlah rantai tambahan keratan sulfat di bagian proksimal dan (3) sejumlah lebih banyak lagi rantai tambahan kondrolitin sulfat distal. Kedua jenis rantai tambahan terjulur secara radial dari molekul protein pusat. Protein penambat menambat molekulmolekul protein pusat pada struktur agregat proteoglikan.

Proteoglikan dan agregat proteo-glikan tulang rawan dengan jelas saling berbaur membentuk sejenis anyaman. Jenis susunan demikian hanya dapat dilihat bila diolah dengan sangat hati-hati (misalnya: dengan memakai proses fikasi ringan yang terkontrol secara teliti dalam keadaan beku [substitusi-beku]). Jalinan ini diduga tertanam pada kerangka penyokong terdiri atas serat-serat kolagen tipe II yang tidak dapat diregangkan, agaknya melalui interaksi antara agregat proteoglikan dan kolagen ini.

Proteoglikan tulang rawan mengikat air dan memberi kekuatan. Sepanjang rantai glikosaminoglikan pada molekul proteoglikan terdapat gugus karboksil dan sulfat yang bermuatan negatif. Keadaan saling menjauh secara elektrostatik antara muatan demikian mengembangkan isi molekul proteoglikan secara maksimal dan memiliki sangat banyak celah untuk menampung molekul dan ion cairan interstisial. Sebagian molekul air interstisial bahkan mengalami pengikatan hidrogen pada gugus bermuatan negatif pada rantai glikosaminoglikan. Susunan demikian mempunyai manfaat ganda. Tidak saja ia menjamin bahwa jalinan proteoglikan akan menangkap dan menahan cukup banyak cairan interstisial, namun melengkapi matriks tulang rawan dengan mekanisme kekuatan intrinsik. Hal ini terjadi karena ada tenaga kompresif yang cukup besar untuk memindahkan molekul air interstisial yang terikat hidrogen dari daerah bermuatan negatif pada rantai glikosaminoglikan, mendekatkan daerahdaerah ini, sehingga daya saling-tolaknya yang meningkat menghadapi tenaga kompresif yang mengakibatkan pemindahan ini.

Protein utama dalam matriks tulang rawan ialah kolagen tipe II dan protein penghubung yang disebut di atas. Kondronektin merupakan glikoprotein yang dihasilkan kondroblas dan yang memperkuat perlekatan sel ini dan kondrosit pada kolagen tulang rawan. Protein matriks lain yang disebut kondrokalsin diduga berperan dalam pengapuran tulang rawan hialin, seperti yang dijelaskan sewaktu membahas kalsifikasi.

Pada sajian hematoksilin dan eosin, matriks tulang rawan hialin terpulas biru pucat atau hampir tidak terpulas warna; walaupun demikian daerah di sekitar kelompok sel isogen (cell nest) terpulas lebih gelap. Hal ini terutama terjadi akibat kandungan glikosaminoglikans bersulfat dari proteoglikan tulang rawan, yang merupakan unsur pokok matriks yang mengelilingi kondrosit. Dikenal sebagai matriks teritorial (kapsular), daerah matriks ini juga terpulas secara metakromatis karena banyaknya glikosaminoglikan, dan terpulas secara positif dengan reaksi PAS karena kandungan glikoproteinnya. Pada daerah paling luarnya, banyak serat kolagen tersusun melingkari kondrosit atau sel-sel isogen. Di antara matriks teritorial kondrosit atau sel-sel isogen dan sel lain di sebelahnya terdapat daerah matriks interteritorial yang terpulas merata.

Akhirnya $65 \%$ sampai $80 \%$ berat basah matriks tulang rawan merupakan cairan 
jaringan yang sebagian terperangkap dan sebagian terikat pada matriks yang memiliki struktur interna yang kompleks. Dapat hidupnya kondrosit yang terpendam itu pada akhrinya tergantung difusi yang mencukupi (adekuat) melalui komponen matriks esensial ini. Tambahan lagi, tulang rawan merupakan jaringan avaskular, artinya tidak memiliki pembuluh dareah kapiler sendiri, meskipun pembuluh yang lebih besar dapat melintasinya tanpa memasoknya; pembuluh limfe pun tidak terdapat dalam jaringan ini. Namun banyaknya cairan jaringan yang tertahan dalam celah-celah jalinan proteoglikan memungkinkan nutrien dan oksigen mencapai kondrositnya melalui difusi jarak-jauh dari kapiler yang terletak di luar tulang rawan itu sendiri. Produk sisa dapat berdifusi dalam arah yang berlawanan memasuki pembuluh demikian. Namun ketergan-tungan mutlak pada difusi jarak jauh ini menimbulkan masalah tersendiri, lebih-lebih bila garam kalsium yang tidak larut telah diendapkan di dalam matriks.

Pada kebanyakan kasus, yang matriks tulang rawannya telah diendapi garam demikian, kondrosit yang terbenam di situ akan diganti oleh jaringan tulang. Jaringan tulang memiliki susunan kanalikuli yang unik, yang memungkinkan matriksnya mengalami pengapuran tanpa mengganggu nutrisi sel-sel di dalamnya.

\section{JENIS-JENIS TULANG RAWAN}

\section{Tulang rawan hialin}

Terpendam dalam matriks intersel tulang rawan hialin mempunyai sel-sel yang dikenal sebagai kondrosit. Sel-sel ini menempati posisi demikian karena alasan berikut. Pada tempat akan dibentuk tulang rawan dalam embrio, sel-sel mesenkim memadat dan berdiferensiasi menjadi sel kondoblas, yang kemudian mulai menghasilkan unsur makromolekul matriks tulang rawan. Pada saat yang sama sel-sel pada bagian tepi mulai membentuk pembungkus fibrosa yang disebut perikondrium (Yun. Peri, sekitar).
Sel-sel pada lapis paling dalam perikondrium berulang-ulang menghasilkan kondroblas baru yang meletakkan matriks tulang rawan baru di atas permukaan bagian yang telah terbentuk, sehingga lapis paling dalam perikondrium ini disebut sebagai lapis kondrogeniknya. Sebaliknya sel-sel pada lapis luar perikondrium berdiferensiasi menjadi fibroblas yang menghasilkan kolagen, dan akibatnya, tulang rawan itu dibungkus jaringan ikat padat tidak teratur yang dikenal sebagai lapis fibrosa perikondrium. Dalam keadaan tertentu bagian fibrosa perikondrium menetap sampai semasa dewasa, namun dalam keadaan lain kedua lapis itu menghilang, sehingga tulan rawan itu terbuka. Tulang rawan sendi merupakan contoh tulang rawan yang tidak dibungkus perikondrium.

Sesudah kondroblas terpendam di dalam matriks tulang rawan, sel itu disebut sebagai kondrosit. Sel itu kemudian tinggal dalam rongga-rongga kecil yang dikenal sebagai lakuna (L. untuk sumur atau rongga kecil) di dalam matriks yang dihasilkannya. Namun luasnya lakuna ini pada sajian MC disebabkan pengisutan (artifak) yang menimbulkan celah buatan di antara kondrosit dan dinding lakuna. Bila kondrosit berhenti menghasilkan substansi intersel ke sekitarnya, lakuna tempat terdapatnya disebut lakuna primer. Namun kondrosit ini mungkin tetap mampu membelah beberapa kali dan bila demikian, ada kecenderungan sel-sel anak itu menetap dalam lakuna yang sama, saling terpisah oleh sekat tipis substansi intersel. Kadangkadang masing-masing sel anak membelah lagi sehingga dengan demikian terdapat empat sel dalam lakuna primer. Karena setiap kondrosit menyekresi cukup substansi intersel untuk membentuk sekat tipis di antara sesama sel, maka sel-sel ini menghuni tempat yang disebut lakuna sekunder dan karenanya lakuna sekunder "cell nest" semuanya terdapat dalam lakuna primer. Sel tulang rawan yang tampak dalam "cell nest" merupakan satu klon (turunan sel "asli" yang menempati lakuna primer). Biasanya 
kondrosit berinti bulat dengan satu atau lebih anak inti. Mungkin terdapat glikogen dan lemak di dalam sitoplasma kondrosit besar. Kondrosit mempunyai ukuran dan bentuk yang bervariasi; biasanya hal ini mencerminkan derajat kematangannya. Kondrosit muda biasanya agak gepeng. Kondrosit matang cenderung besar dan bulat. Jadi ukuran merupakan petunjuk penting tingkat kematangan kondrosit.

Dengan cara pembuatan sajian mikroskop elektron kini jelas bahwa kondrosit hidup mengisi lakuna secara penuh. Tersebar di antara kromatin terurai di dalam inti yang bulat-lonjong terdapat kelompokan kecil kromatin padat, yang juga tampak pada tepi inti. Sitoplasmanya penuh dengan organel sekresi yang tersusun secara tidak terpolarisasi. Terdapat banyak sisterna retikulum endoplasma kasar, dan biasa melebar oleh produk sekresi. Juga terdapat cukup banyak glikogen di dalam sitoplasma.

\section{Tulang rawan elastis}

Tulang rawan elastis merupakan bentuk tulang rawan yang sangat kenyal yang khusus diperuntukkan menahan akibat pembengkokan. Jenis tulang rawan ini menyokong telinga luar dan epiglotis. Tulang rawan elastis menyerupai tulang rawan hialin kecuali bahwa selain serat kolagen tipe II yang tersebat luas, matriksnya mengandung serat-serat elastin. Kondroblas menghasilkan semua komponen matriks dan kemudian terbenam sebagai kondrosit di dalam matriks yang dihasilkannya. Sebagaimana halnya pada tulang rawan hialin, kondrosit terletak dalam lakuna dan beberapa terdapat berupa sel-sel isogen. Lagi pula jenis tulang rawan ini tetap memiliki perikondrium sampai dewasa.

\section{Tulang rawan fibrosa (fibrokartilago)}

Fibrokartilago dengan mudah dipelajari pada tempat tertanamnya tendo pada tulang rawan. Mendekati tempat tertanamnya, tendo berubah wujudnya. Pada tempat tendo tertanam ke dalam tulang rawan, kolagen dibentuk oleh kondroblas dan bukan oleh fibroblas. Pada tempat insersi, sel-selnya lebih besar dan lebih bulat daripada fibroblas dan berderet di antara berkas-berkas kolagen yang paralel. Di antara sel-sel ini terdapat matriks amorf basofilik yang menyerupai matriks teritorium tulang rawan hialin (matriks yang terpulas lebih gelap di sekitar sel-sel isogen pada bagian bawah). Di sini pun basofilia disebabkan kandungan glikosaminoglikans bersulfat.

Fibrokartilago bersifat avaskular, dan semasa dewasa tidak memiliki perikondrium. Selain terdapat pada insersi tendo, fibrokartilago terdapat di simfisis pubis dan diskus intervertebrata.

\section{NUTRISI DAN PERBAIKAN}

Tulang rawan tidak terdapat pembuluh darah intrinsik, saraf, dan pembuluh limfe. Bahan makanan, oksigen dan buangan sel harus merembes melalui matriks secara difusi dari perikondrium. Avaskularitas mengakibatkan lambatnya proses metabolisme pada tulang rawan dewasa dan juga perlambatan atau penghambatan respons terhadap kerusakan atau cedera.

Trauma yang menyebabkan cedera pada tulang rawan akan diperbaiki oleh perikondrium. Sel-sel perikondrium cenderung untuk mengisi kekosongan atau defek dan sel-sel kondrogenik dalam perikondrium akan berproliferasi dan berdiferensiasi menjadi kondroblas yang menghasilkan matriks baru.

Tulang rawan dipengaruhi oleh adanya defisiensi protein, mineral dan vitamin. Sebagai contoh, dibutuhkan vitamin A, C, $\mathrm{D}$, kalsium, dan fosfor dalam kadar yang baik untuk perkembangan normal tulang rawan. Hormon perangsang-pertumbuhan dan hormon-hormon yang lain juga memengaruhi perkembangan tulang rawan.

\section{PENCANGKOKAN TULANG RAWAN}

Epidermis dan tulang rawan keduanya merupakan organ avaskuler dan sering dapat ditransplantasikan dengan berhasil. 
Tulang rawan dapat ditransplantasikan dalam satu individu yag sama (autograft). Pencangkokan tulang rawan antara individu (homograft) juga dapat dilakukan, seperti pada perbaikan tulang rawan hidung dan telinga. Tulang rawan yang akan dicangkokkan harus terus hidup sebab tulang rawan yang sudah mati akan diresorbsi oleh tempat dicangkokkan (host). Cangkokan harus bervaskularisasi baik untuk memasok kebutuhan makanan.

Terdapat beberapa kemungkinan mengapa cangkok tulang rawan ini biasanya tidak terjadi penolakan. Matriks tulang rawan tampaknya bukan merupakan suatu antigen yang sangat poten, tetapi justru kondrosit yang antigennya lebih poten namun sel ini akan "disembunyikan" oleh matriks tulang rawan terhadap sel-sel host yang dapat mengenali mereka sebagai benda asing atau antigen. Antibodi dan limfosit tidak mudah bergerak menuju ke matriks intersel tulang rawan.

\section{Alograf tulang rawan hialin cocok untuk bedah rekonstruksi}

Kesulitan utama dalam bedah rekonstruksi ialah bahwa terdapat sedikit tulang rawan ekstra-skelet yang dapat dipakai untuk autograf. Oleh sebab itu bila hidung atau telinga memerlukan pembedahan rekonstruksi besar, maka tidak cukup tersedia tulang rawan autolog. Namun untungnya alograf tulang rawan hialin yang diperoleh dari korban kecelakaan yang meninggal ternyata memberi hasil yang cukup memuaskan.

Sebelum dibahas mengapa cangkokan (graf) demikian dapat bertahan, perlu ditegaskan bahwa agar cangkokan tulang rawan dapat bertahan, kondrositnya harus tetap hidup dan dapat menghasilkan proteoglikan tulang rawan. Cangkokan tulang rawan mati akan diserbu kapiler dan fibroblas dan akhirnya diresorpsi, tetapi matriks tulang rawan hidup mampu menghalangi serbuan demikian. Selama dasar cangkokan itu menyediakan cukup nutrien dan oksigen, alograf tulang rawan dapat tahan hidup bertahun-tahun lamanya.
Hal ini disebabkan kondrosit-kondrositnya terbenam dalam matriks yang membatasi difusi substansi dengan berat molekul tinggi dan karenanya cenderung menghalangi antigen asing kondrosit dalam alograf berhubungan dengan sistem imun tuan rumah. Akibatnya, alograf tulang rawan tidak begitu imunogenik. Namun faktor yang bahkan lebih penting ialah bahwa matriks ini merupakan sawar fisik antara kondrosit yang dicangkokkan dan jaringan (tuan rumah) di sekitarnya. Karenanya, walaupun sel-T sitotoksik dibentuk, mereka tidak dapat berkontak langsung dengan sel sasaran, dan tanpa kontak ini, tidak dapat membunuh sel-sel demikian. Akhirnya, matriks cangkokan tulang rawan yang hidup dapat menahan masuknya pembuluh darah dari dasar cangkokan, dan tetap tidak dapat ditembus molekul antibodi apapun yang dibentuk.

\section{KALSIFIKASI TULANG RAWAN}

Kalsifikasi selalu terjadi pada tulang rawan, hal ini untuk mempersiapkan tulang rawan digantikan menjadi tulang pada waktu yang tepat dalam pertumbuhan individu. Juga, bagian tulang rawan sendi yang berhubungan

dengan tulang juga akan mengalami kalsifikasi. Selain itu, beberapa kalsifikasi tulang rawan hialin dalam tubuh dapat terjadi sebagai bagian dari proses penuaan.

Sebagian besar bakal tulang diawali dari model tulang rawan dan bertumbuh secara cepat dalam janin. Hal ini penting untuk menggantikan tulang rawan dengan tulang pada waktu yang tepat. Peristiwa ini akan dicapai lebih lambat melalui kalsifikasi tulang rawan yang menyebabkan kematian kondrosit dan erosi lambat dari matriks tulang rawan.

Terdapat beberapa kebutuhan penting untuk kalsifikasi tulang rawan. Ion-ion kalsium dan fosfat harus ada dalam konsentrasi cukup dalam matriks. Sinar matahari dan vitamin D merupakan hal penting, dalam keadaan kekurangan vitamin $\mathrm{D}$ dan paparan sinar matahari pada anak-anak dapat menyebabkan turunnya 
kadar kalsium dan fosfat di bawah titik kritis yang mengakibatkan terjadinya riketsia. Kadar $\mathrm{pH}$ merupakan faktor penting pada kalsifikasi matriks tulang rawan. Pada $\mathrm{pH}$ basa, kalsium fosfat $\left(\mathrm{Ca}_{3}\left(\mathrm{PO}_{4}\right)_{2}\right)$ merupakan presipitat tidak larut. Sebaliknya, pada $\mathrm{pH}$ asam kalsium hidrogen fosfat $\left(\mathrm{CaHPO}_{4}\right)$ merupakan presipitat sangat larut. Jadi, alkalinitas menyokong kalsifikasi, sedangkan asiditas menghambat kalsifikasi. Suatu protein yang disebut kodrokalsin berperan penting dalam proses kalsifikasi matriks tulang rawan. Suatu tanda awal dari kalsifikasi matriks tulang rawan adalah pembesaran atau hipertrofi yang terjadi pada kondrosit. Hipertrofi berhubungan dengan produksi ensim alkalin fosfatase oleh kondrosit. Alkalin fosfatase dapat menghidrolisis substrat yang mengandung fosfat organik; ensim tersebut dapat menyebabkan pelepasan ion $\mathrm{Ca}^{2+}$ dan $\mathrm{P}_{\mathrm{i}}$ dari kalsium $\beta$ gliserofosfat. Ensim alkalin fosfatase tampaknya penting dalam meningkatkan kadar ion kalsium dan fosfat lokal yang cukup untuk kristal kalsium dalam membentuk. Mitokondria kondrosit dapat menyimpan ion kalsium untuk pelepasan pada saat kalsifikasi matriks. Glikosaminoglikan sulfat dan proteoglikan dapat mengikat ion kalsium dengan demikian berpartisipasi dalam kalsifikasi, dan protein kondrokalsin konsentrasinya meningkat dalam matriks tulang rawan sebelum kalsifikasi. Kondrokalsin mengikat $\mathrm{Ca}^{2+}$ dengan afinitas kuat. Pada waktu kalsifikasi matriks tulang rawan dimulai, lipid dan glikogen yang disimpan dalam kondrosit lokal yang hilang. Jadi, penggunaan lipid dan karbohidrat nampaknya merupakan peristiwa penting dalam menghasilkan substrat yang sesuai untuk alkalin fosfatase. Kalsifikasi tulang rawan merupakan suatu tahap awal penting dalam penulangan endokondral atau intrakartilagenosa.

Untuk terjadinya kalsifikasi matriks tulang rawan membutuhkan peningkatan setempat dari ion-ion kalsium dan fosfat. Pada waktu faktor setempat kondusif untuk meningkatkan ion-ion, maka akan muncul mikrokristal dari hidroksiapatit. Sekali mikrokristal mulai dibentuk, mereka tidak hanya akan bertumbuh tetapi juga lebih lanjut akan mengkatalisa kristalisasi kalsium fosfat. Dapat diamati dengan mikroskop elektron transmisi bahwa pada daerah kalsifikasi matriks tulang rawan terdapat vesikel matriks berbatas membran yang diduga dibentuk melalui kuncup dari permukaan kondrosit hipertrofi. Kristral hidroksiapatit dibentuk berhubungan erat dengan vesikel matriks ini, yang juga dilepaskan dari osteoblas dan odontoblas selama kalsifikasi. Vesikel-vesikel matriks nampak menjadi tempat pertama pembentukan kalsium fosfat selama kalsifikasi. Matriks vesikel terisolasi mengandung alkalin fosfatase dan kadar tinggi ATPase. Alkalin fosfatase merupakan suatu ektoensim dalam membran matriks vesikel dan nampaknya bekerja sebagai fosfat transferase pada substrat yang cocok, kemungkinan fosfatidiletanolamin, untuk meningkatkan konsentrasi $\mathrm{P}_{\mathrm{i}}$ dalam vesikel. ATPase yang terdapat dalam vesikel nampak menjadi aktif dalam operasi pompa kalsium pada membran vesikel. Kondrosit hipertrofi membentuk vesikel matriks mengandung alkalin fosfatase dalam keadaan in vitro.

\section{HISTOFISIOLOGI TULANG RAWAN}

Matriks ekstrasel khusus tulang rawan memungkinkannya menahan kekuatan kompresi besar pada sambungan antara tulang penahan-beban, dan pada waktu bersamaan memungkinkan gerakan sendi halus dan tapa gesekan. Kesanggupan tulang rawan tumbuh secara interstisial memungkinkan pertumbuhan memanjang tulang panjang tungkai. Ia tampaknya adalah materi struktural avaskuler yang relatif tak giat, namun dalam keikutsertaannya dalam pertumbuhan tulang ia sebenarnya merupakan indikator cukup sensitif terhadap defisiensi nutrisi protein mineral, dan vitamin. Bila hewan muda diberi diet rendah-protein, atau yang tanpa vitamin A, maka ketebalan lempeng epifiser dengan cepat mengurang. Bila 
vitamin C tidak diberikan pada marmot, berakibat scurvy, maka tidak ada produksi matriks dan distorsi susunan berkolom sel dalam lempeng epifiser. Kekurangan absorpsi kalsium dan fosfat dari makanan, akibat tiadanya vitamin $\mathrm{D}$, berakibat rachitis, suatu keadaan di mana sel-sel tulang rawan epifisis terus berprolifersi namun matriks tidak mengapur dan tulang yang tumbuh akan melengkung oleh beban.

Memanjangnya tulang juga dipengaruhi hormon, diantaranya yang terpenting adalah hormon penumbuh (somatotrofin) hipofosis. Hipofisektomi pada tikus muda berakibat menipisnya lempeng epifiser tulang panjang akibat terhentinya mitosis dan mengecilnya ukuran dan jumlah kondrosit. Tulang rawan tidak dikikis lagi di dasar kolom sel dan pertumbuhan terhenti. Bila hormon penumbuh disuntikkan ke dalam hewan demikian, tulang rawan epifisis pulih kembali dan pertumbuhan tulang berlanjut lagi. Pemberian hormon itu secara berkepanjangan menghasilkan tikus raksasa, sebagian karena pertumbuhan tulang rawan berlanjut terus, saat lempeng epifiser normalnya sudah hilang.

Pada tulang rawan sendi, kolagen agaknya abadi, namun proteoglikan secara perlahan diganti baru oleh molekul yang baru disintesis. Ada bukti bahwa kini proteoglikan yang dihasilkan berubah dengan meningkatnya usia. Jika kondrosit yang telah dipisahkan dari tulang rawan sendi hewan tua dibiak, maka mereka menghasilkan proteoglikan yang lebih kecil, dengan rantai kondroitin sulfat lebih pendek dibanding yang dihasilkan in vitro oleh kondrosit individu muda. Ada kemungkinan bahwa prevalensi osteoartritis pada orang tua berhubungan dengan perubahan demikian dalam matrik tulang rawan. Diduga bahwa proteoglikan lebih kecil akan menyusun lebih sedikit air dan kurang mampu menahan kekuatan kompresi. Matriks akan lebih peka terhadap cedera kecil dalam menahan beban yang berulang, dan respons radang terkait terhadap cedera akan berakibat gejala nyeri artritis.
Tulang rawan hialin sangat terbatas kemampuan pemulihannya. Sel-selnya tergantung pada difusi nutrien dan oksigen yang harus menempuh jarak lumayan melalui matriks. Jika aliran darah ke jaringan sekitar tulang rawan berkurang, sel-selnya dapat mati. Tulang rawan itu kemudian dimasuki pembuluh darah dan fagosit dan matriks diserap dan diganti oleh jaringan parut. Diduga bahwa kondrosit menghasilkan sebuah faktor yang secara khas menghambat masuknya pembuluh darah. Ekstrak tulang rawan ternyata menekan vaskularisasi jaringan yang umumnya dipakai dalam studi percobaan angiogenesis. Fakor ini belum berhasil diisolasi dan dipelajari.

Sifat unik matriks ekstrasel tulang rawan memiliki manfaat klinik menarik bagi bedah rekonstruktif. Seperti diketahui, pencangkokan jaringan dari satu orang ke orang lain diikuti penolakan, kecuali diambil tindakan penekanan sistem imun yang menerima. Tulang rawan itu luar biasa karena ia dapat diambil dari korban kecelakaan fatal dan dipakai dalam bedak kosmetik atau rekonstruktif orang lain tanpa imuno-superesi. Hal ini dikarenakan avaskulernya tulang rawan dan impermeabilitasnya terhadap molekul sebesar imunoglobulin. Matriksnya juga merupakan sawar yang tak dapat diterobos oleh limfosit sitotoksik, mencegahnya dari berkontak dan menghancurkan kondrosit donor. Jika tulang rawan cangkokan ditempatkan pada dasar sangat vaskuler, sel-selnya akan memperoleh, melalui difusi, cukup oksigen dan nutrien untuk tahan hidup.

\section{SIMPULAN}

Karena tulang rawan tidak mempunyai pembuluh darah intrinsik, saraf, dan pembuluh limfe, maka bahan makanan, oksigen dan buangan sel harus merembes melalui matriks secara difusi dari perikondrium. Hal ini menyebabkan lambatnya proses metabolisme pada tulang rawan dewasa dan juga pengham-batan respons terhadap kerusakan atau cedera. 
Matriks ekstrasel tulang rawan memungkinkan menahan kekuatan kompresi besar pada sambungan antara tulang penahan-beban, dan pada waktu bersamaan memungkinkan gerakan sendi halus dan tanpa gesekan. Kesanggupan tulang rawan tumbuh secara interstisial memungkinkan pertumbuhan memanjang tulang panjang tungkai.

\section{DAFTAR PUSTAKA}

1. Bergman RA, Afifi KA, Heidger Jr PM. Histology. Philadelphia: WB Saunders Company, 1996.
2. Cormack DH. Ham's Histology (Ninth Edition). Philadelphia: JB Lippincott Company, 1987.

3. Fawcett DW. Bloom and Fawcett: A Textbook of Histology (Twelfth Edition). New York: Chapman \& Hall, 1994.

4. Kessel RG. Basic Medical Histology. The biology of Cells, Tissues, and Organs. New York: Oxford University Press, 1998.

5. McKenzie JC, Klein RM. Basic Concepts in Cell Biology and Histology. A Student's Survival Guide. New York: McGraw-Hill, 2000. 